\title{
PROFIL PENGETAHUAN MAHASISWA INSTITUT TEKNOLOGI SEPULUH NOPEMBER TERHADAP PENGGUNAAN OBAT ANTASIDA
}

\author{
Ersalia Susetyo, Ermawati Dwi Agustin, Hurindina Hanuni, Rafiqa Amalia Chasanah, Elda Yuliana Dwi \\ Lestari, Rana, Yehezkiel Alfa Ludji Leo, Zulfia Almas Rizqulloh, Galina Meldaviati, Jamilatul Fardha, \\ Ferri Febriansyah, Didy Pratama Maylana Susanto, Faridatus Sholikah, Liza Pristianty*
}

Departemen Farmasi Komunitas, Fakultas Farmasi, Universitas Airlangga Gedung Nanizar Zaman Joenoes Kampus C, Jl. Ir. Soekarno, Surabaya 60115, Indonesia

E-mail: liza-p@ff.unair.ac.id

\begin{abstract}
ABSTRAK
Obat terapi gastritis yang banyak digunakan di kalangan mahasiswa adalah antasida. Pengetahuan tentang antasida berpengaruh terhadap ketepatan penggunaan obat antasida yang berdampak pada keberhasilan terapi. Penelitian ini bertujuan mengetahui profil pengetahuan mahasiswa Institut Teknologi Sepuluh Nopember terhadap penggunaan obat antasida. Penelitian ini bersifat observasi melalui metode survei menggunakan instrumen kuesioner, berdasarkan waktu cross sectional. Sejumlah 130 orang sampel diambil dengan menggunakan teknik accidental sampling. Data dianalisis dengan cara skoring jawaban pertanyaan kuesioner. Hasil penelitian menunjukkan bahwa mahasiswa dengan pengetahuan penggunaan obat antasida yang baik sebesar 61(47\%) orang dan pengetahuan cukup 69(53\%) orang, sedangkan dari total responden tersebut yang pernah mengalami maag sebanyak 84 (66\%) orang dan sisanya sebanyak $44(34 \%)$ orang belum pernah mengalaminya. Sejumlah $75(58 \%)$ orang mendapatkan obat dari apotek, sedangkan sisanya memperoleh dari tempat lain. Pengetahuan yang baik tentang penggunaan obat akan meningkatkan keberhasilan terapi. Upaya promosi kesehatan merupakan hal penting untuk meningkatkan pengetahuan mahasiswa tentang penggunaan obat antasida yang benar.
\end{abstract}

Kata kunci: pengetahuan, mahasiswa, antasida

\begin{abstract}
Gastritis therapy drugs that are widely used among colleges are antacid. Incorrect knowledge of the use of antacid drugs will have an effect on the success of therapy. This study tried to determine the profile of the knowledge the Institute Teknologi Sepuluh Nopember's colleges on the use of antacid drugs. This research is an observational, survey method with cross sectional timing using a questionnaire instrument. A total of 130 samples were taken using accidental sampling technique. The data were analyzed by means of scoring the answers to the questionnaire. The results showed students with good knowledge of using antacid drugs by 61(47\%) people and sufficient knowledge of 69(53\%) people, while of the total respondents who had experienced gastritis as much as $84(66 \%)$ people and the remaining $44(34 \%)$ people had never experienced it. As many as 75 (58\%) people received drugs from the pharmacy, while the rest obtained from other places. Good knowledge of drug use will increase the therapeutic success. Health promotion efforts are important for colleges to do the correct used of antacid drugs.
\end{abstract}

Keywords: knowledge, student, antacid 


\section{PENDAHULUAN}

Gastritis merupakan penyakit akibat proses inflamasi pada mukosa dan submukosa lambung (Pasaribu, 2014). Menurut WHO, insiden gastritis sekitar 1,8-2,1 juta tiap tahun. Angka kejadian di Indonesia adalah 40,8\% dengan prevalensi 274.396 kasus dari 238.452.952 jiwa penduduk (Depkes RI, 2011). Gastritis menduduki peringkat 10 besar pasien rawat inap di rumah sakit Indonesia dengan jumlah 30.154 kasus (4,9\%) (Kementerian Kesehatan RI, 2012). Prevalensi gastritis di Indonesia sangat tinggi dengan prevalensi di Kota Surabaya (31,2\%), Denpasar (46\%) dan di Propinsi Jawa Tengah (79,6\%) (Sulastri, Siregar dan Siagian, 2012).

Gastritis disebabkan oleh banyak faktor, diantaranya adalah pola makan tidak teratur serta gizi makanan yang tidak seimbang, penggunaan obat NSAID, infeksi kuman Helicobacter pylori, minum minuman beralkohol, memiliki kebiasaan merokok, sering mengalami stres, serta kebiasaan minum kopi. Pola makan yang tidak teratur dalam jangka waktu yang lama dapat menyebabkan terjadinya peningkatan risiko infeksi $H$. pylori dan gastritis (Lim et al. 2012). Selain perlunya menjaga pola makan, hal lain yang mempengaruhi faktor terjadinya gastritis adalah kecepatan makan. Kecepatan makan yang tinggi menunjukkan salah satu faktor risiko terjadinya gastritis erosif. Penelitian menunjukkan kecepatan makan yang tinggi ( $<5$ menit/makan) memiliki risiko $1,7 \mathrm{kali}$ lebih tinggi terjadi gastritis dibandingkan kelompok dengan kecepatan makan rendah (>15 menit/makan) (Kim et al. 2015).

Gastritis merupakan penyakit yang sering dijumpai di masyarakat namun juga sering diabaikan karena dianggap sebagai penyakit yang sepele. Masyarakat pada umumnya tetap melakukan hal-hal yang dapat memicu kambuhnya gastritis. Kematian akibat gastritis memang jarang terjadi, namun kematian dapat terjadi karena gastritis yang tidak segera diobati. Oleh sebab itu, masyarakat perlu mengetahui gejala yang timbul apabila memiliki penyakit gastritis dan saat kambuh sebagai upaya preventif timbulnya penyakit baru atau risiko yang fatal. Secara umum beberapa gejala gastritis yang perlu diperhatikan masyarakat yaitu sering ditandai dengan gangguan pencernaan antara makan atau malam hari, nyeri hebat pada perut, kesulitan menelan, penurunan berat badan, perut terasa kembung, mual, sering muntah, dan rasa sakit yang disebabkan ketika olahraga atau aktivitas berlebih (Nathan, 2008).

Usia yang rentan terkena gastritis yaitu pada usia 15-45 tahun karena pada usia tersebut merupakan rentang usia produktif dalam bekerja dengan tekanan pekerjaan yang berlebihan. Pada usia produktif sering berhadapan dengan tantangan, dan apabila tidak mampu mengaturnya bisa berpotensi stres. Namun, lansia juga memiliki risiko yang cukup besar terkena gastritis. Seiring bertambahnya usia mukosa lambung cenderung menjadi tipis sehingga lebih mudah terinfeksi Helicobacter pylory atau gangguan autoimun (Gustin, 2011). Kebiasaan merokok meningkatkan risiko terkena penyakit gastritis karena merokok dapat mengganggu kerja lapisan pelindung lambung dan meningkatkan asam lambung sehingga menunda penyembuhan lambung dan penyebab utama terjadinya kanker lambung. Konsumsi alkohol dengan dosis rendah ataupun sedang dapat menyebabkan perubahan pada produksi asam lambung, dan cedera pada mukosa lambung, serta memengaruhi pergerakan lambung dan usus. Sedangkan pada dosis tinggi alkohol bisa menyebabkan luka pada lambung dan perdarahan. Konsumsi alkohol kronis juga menyebabkan penyusutan mukosa lambung sehingga mengurangi kemampuannya memproduksi asam lambung (Natun, Candrawati dan Warsono, 2017).

Salah satu faktor risiko yang menyebabkan terjadinya gastritis diantaranya adalah konsumsi kafein. Kafein biasanya paling banyak ditemukan pada produk minuman seperti kopi (Susanti, Briawan dan Uripi, 2011). Pada tahun 2009, terjadi peningkatan konsumsi kopi harian pada remaja berusia 18-24 tahun. Konsumsi kopi sebagai sumber utama kafein di Indonesia sendiri mengalami peningkatan sebesar $98 \%$ dalam 10 tahun terakhir (Liveina dan Artini, 2014). Kafein yang terdapat pada kopi pada sistem gastrointestinal akan meningkatkan sekresi gastrin sehingga akan merangsang produksi asam lambung. Tingginya asam menyebabkan peradangan serta erosi pada mukosa lambung sehingga dapat memunculkan gangguan dispepsia (Putri, Ernalia dan Bebasari, 2015). Konsentrasi luminal yang tinggi dari $\mathrm{HCl}$ membahayakan integritas mukosa di lambung dan daerah yang berdekatan dari saluran pencernaan. Sistem perlindungan lambung dari asam yang kurang baik dapat menyebabkan terjadinya penyakit terkait asam termasuk penyakit refluks gastroesofagus (GERD), dispepsia, gastritis dan penyakit maag gastroduodenal dapat terjadi (Holzer, 2015). Oleh sebab itu, penting untuk 
menjaga perut tetap dalam keadaan terisi agar asam lambung tidak mencerna lapisan mukosa lambung yang menimbulkan rasa nyeri.

Penggunaan obat golongan Non Steroid Anti Inflammatory Drug (NSAID) sebagai obat penekan nyeri dapat memengaruhi terjadinya gastritis melalui dua mekanisme yaitu mekanisme lokal dan sistemik. Pada mekanisme lokal gastritis terjadi karena NSAID bersifat lipofilik dan asam sehingga mempermudah penangkapan ion hidrogen masuk mukosa lambung dan menimbulkan kerusakan. Pada mekanisme sistemik, gastritis terjadi karena kerusakan mukosa akibat produksi prostaglandin yang menurun secara bermakna, dimana prostaglandin merupakan substansi sitoproteksi yang amat penting bagi mukosa lambung. Hal ini dimungkinkan karena pekerjaan yang harus diselesaikan dalam tenggang waktu dekat yang membuat pola makan mereka menjadi tidak teratur dan tidak sehat. Hal ini membuat pegawai swasta berisiko mengalami keluhan gejala gastritis. Stres atau mendapat tekanan bisa berpotensi terkena gastritis karena stres memiliki efek negatif melalui mekanisme neuroendokrin terhadap saluran pencernaan sehingga berisiko untuk mengalami gastritis (Megha, Farooq, and Lopez, 2020).

Semua orang dapat mengalami stres. Tak terkecuali para mahasiswa, kehidupan di perguruan tinggi juga meliputi adanya perubahan pengambilan keputusan dan penyesuaian. Seorang mahasiswa akan menghadapi serangkaian beban studi dan kewajiban yang harus diselesaikannya dalam mencapai gelar sarjana yang sesuai dengan bidang yang dipilihnya. Banyaknya beban tugas yang dipikul oleh mahasiswa rentan membuatnya stres bahkan hingga lupa waktu untuk mengatur pola makan. Hal tersebut dapat menyebabkan mahasiswa mengalami gangguan secara fisik, emosional, intelektual, dan interpersonal. Salah satu gangguan fisik yang terjadi adalah gastritis berefek pada proses menjalani kehidupan namun juga pada kesehatan.

\section{METODE PENELITIAN}

Penelitian dilakukan di Institut Teknologi Sepuluh Nopember, Surabaya, Jawa Timur, Indonesia pada minggu kedua bulan September 2019 dengan melibatkan 13 orang peneliti yang merupakan mahasiswa S1 Farmasi Universitas Airlangga semester 7. Penelitian ini merupakan penelitian observasional, berdasarkan waktu pengambilan data tergolong kedalam penelitian cross sectional. Data diperoleh melalui kegiatan survei dengan instrumen berupa kuesioner. Semua peneliti turun langsung ke lapangan untuk mendapatkan data. Survei dilakukan dengan metode accidental sampling. Metode ini memudahkan peneliti untuk meneliti populasi yang besar.

\section{Besar Sampel}

Populasi pada penelitian ini adalah mahasiswa Institut Teknologi Sepuluh Nopember. Sampel pada penelitian ini adalah mahasiswa Institut Teknologi Sepuluh Nopember yang memenuhi kriteria inklusi, yaitu mahasiswa aktif Institut Teknologi Sepuluh Nopember yang bersedia menjadi responden penelitian, dibuktikan dengan menyetujui lembar informed consent.

Populasi mahasiswa yang besar dan tidak diketahui secara pasti jumlahnya sehingga dilakukan perhitungan besar sampel minimal dengan menggunakan Rumus Lemeshow sebagai berikut:

\section{Keterangan :}

$$
\mathrm{n}=\frac{z \alpha^{2} \mathrm{pq}}{d^{2}}=\frac{z^{2} \mathrm{p}(1-\mathrm{q})}{d^{2}}
$$

$\mathrm{n}=$ jumlah sampel minimal yang diperlukan

$\mathrm{z} \alpha=$ nilai standar dari distribusi sesuai nilai $\alpha=$ $5 \%=1.96$

$\mathrm{p}=$ prevalensi outcome,karena data belum didapat, maka dipakai $50 \%$

$\mathrm{q}=1-\mathrm{p}$

$\mathrm{d}=$ tingkat ketelitian $10 \%$

Sesuai rumus tersebut, jumlah sampel minimal adalah 96 orang. Sebelum dilakukan penelitian, responden yang terlibat diberikan penjelasan secara lisan dan tertulis tentang survei yang akan dilakukan. Penjelasan berupa gambaran umum, tujuan, manfaat, hak, dan kewajiban responden. Informed consent merupakan bukti tertulis bahwa responden bersedia menjadi sample dari penelitian.

Metode untuk pengambilan data yang digunakan adalah non-random dengan teknik accidental sampling. Besar sampel sejumlah 130 responden.

\section{Variabel}

Variabel penelitian berupa pengetahuan tentang penyakit maag dan pengetahuan tentang obat antasida. Variabel mengenai pengetahuan tentang penyakit maag terdiri dari beberapa indikator, yaitu pengertian tentang maag, gejala penyakit maag, frekuensi mengalami maag, pola hidup responden, serta cara mengatasi gejala maag. Sedangkan indikator pada variabel pengetahuan tentang 
obat antasida adalah cara mendapatkan obat antasida, waktu penggunaan, bentuk sediaan, cara penggunaan, dosis, efek samping, cara penyimpanan obat, dan cara pembuangan obat.

\section{Instrumen}

Instrumen survei yang digunakan adalah kuesioner. Kuesioner berisikan sekumpulan pertanyaan tertulis yang harus dijawab oleh responden. Pengumpulan data menggunakan kuesioner yang diberikan langsung kepada responden. Teknik ini meminimalkan terjadi kehilangan data, mencegah terjadinya ketidaklengkapan data yang diisi oleh responden, serta menghindari data tidak valid karena responden dapat bertanya apabila kurang memahami pertanyaan di kuesioner.

Kuesioner berisi 22 butir pertanyaan yang terdiri dari 18 butir pertanyaan tentang pengetahuan responden terhadap obat antasida dengan jawaban ya/tidak, dan terdapat 4 butir pertanyaan tentang perilaku responden. Sebelumnya, responden harus mengisi identitas pribadi untuk memudahkan pendataan.

\section{HASIL DAN PEMBAHASAN}

\section{Data Demografi Responden}

Penelitian ini menggunakan sampel sejumlah 130 responden. Data sosiodemografi dapat dilihat pada Tabel 1. Proporsi responden berjenis kelamin perempuan lebih besar dari laki-laki yaitu sebesar $71 \%$. Hal tersebut sesuai dengan penelitian sebelumnya bahwa perempuan tiga kali lebih berisiko terkena gangguan gastritis dibanding laki-laki karena laki-laki lebih toleran untuk terhadap rasa sakit dan gejala gastritis (Anggita, 2012).

Tempat tinggal mayoritas responden adalah tempat kos dengan proporsi sejumlah $67,7 \%$. Kemungkinan penggunaan antasida lebih tinggi pada responden yang bertempat tinggal di kos karena tidak ada pengawasan langsung dari orang tua sehingga pola makan tidak teratur dan mengonsumsi makanan yang kurang sehat. Variasi data demografi berdasarkan fakultas dan tingkat semester diharapkan dapat mewakili seluruh mahasiswa Institut Teknologi Sepuluh Nopember.

Responden merupakan mahasiswa usia produktif dengan mayoritas berusia 18 tahun sebesar $46 \%$. Pada usia produktif, tingkat kesibukan tinggi dan faktor stres dari lingkungan juga tinggi. Sebagian besar asam diproduksi ketika $\mathrm{pH}$ lambung merangsang pelepasan gastrointestinal menggunakan pelepasan dan aktivasi berbagai enzim pencernaan. Sekresi ion hidrogen dirangsang oleh tiga zat dominan, yaitu neurotransmitter asetilkolin (ACH), gastrin, dan histamin. Disregulasi mekanisme sekresi ion hidrogen oleh zat tersebut dapat menyebabkan terjadinya gastropati hemoragik atau erosif, dikenal juga sebagai gastritis stres (Megha, Farooq, and Lopez, 2020). Tingginya beban perkuliahan dan/atau organisasi serta pola makan yang tidak teratur merupakan pemicu terjadinya gastritis pada mahasiswa.

Tabel 1. Data Demografi Responden

\begin{tabular}{|c|c|c|c|}
\hline $\begin{array}{l}\text { Demografi } \\
\text { Responden }\end{array}$ & $\begin{array}{l}\text { Kategori } \\
\text { Jawaban }\end{array}$ & $\begin{array}{l}\text { Jumlah } \\
\text { (n) }\end{array}$ & $\%$ \\
\hline \multirow{2}{*}{ Jenis Kelamin } & Laki-Laki & 59 & 45,38 \\
\hline & Perempuan & 71 & 54,62 \\
\hline \multirow{4}{*}{$\begin{array}{l}\text { Tempat } \\
\text { Tinggal }\end{array}$} & Kos & 88 & 67,69 \\
\hline & $\begin{array}{l}\text { Bersama } \\
\text { Orangtua }\end{array}$ & 28 & 21,54 \\
\hline & $\begin{array}{l}\text { Bersama } \\
\text { Kerabat }\end{array}$ & 6 & 4,62 \\
\hline & Lain-Lain & 8 & 6,15 \\
\hline \multirow{7}{*}{ Usia } & 17 & 8 & 6,15 \\
\hline & 18 & 46 & 35,38 \\
\hline & 19 & 24 & 18,46 \\
\hline & 20 & 31 & 23,85 \\
\hline & 21 & 15 & 11,54 \\
\hline & 22 & 4 & 3,08 \\
\hline & 25 & 2 & 1,54 \\
\hline \multirow{9}{*}{ Fakultas } & FIA & 6 & 4,62 \\
\hline & FTI & 26 & 20,00 \\
\hline & FTE & 14 & 10,77 \\
\hline & FTSLK & 10 & 7,69 \\
\hline & FADP & 5 & 3,85 \\
\hline & FTK & 7 & 5,38 \\
\hline & FMKSD & 29 & 22,31 \\
\hline & FBMT & 10 & 7,69 \\
\hline & FV & 23 & 17,69 \\
\hline \multirow{7}{*}{$\begin{array}{l}\text { Tingkat } \\
\text { Semester }\end{array}$} & 1 & 52 & 40,00 \\
\hline & 3 & 22 & 16,92 \\
\hline & 4 & 2 & 1,54 \\
\hline & 5 & 38 & 29,23 \\
\hline & 7 & 14 & 10,77 \\
\hline & 8 & 1 & 0,77 \\
\hline & 9 & 1 & 0,77 \\
\hline
\end{tabular}

\section{Data Pengetahuan Responden}

Profil pengetahuan responden terkait penyakit gastritis ditunjukkan pada Gambar 1 . Responden yang menjawab benar bahwa gastritis adalah penyakit akibat produksi asam lambung berlebih sebesar 95,4\% ( $n=124)$. Responden yang menjawab benar bahwa gastritis yang tidak ditangani dengan baik akan berisiko menyebabkan kanker lambung sebesar $70 \%(n=91)$. Berdasarkan kedua data tersebut dapat dinyatakan bahwa profil pengetahuan responden terkait penyakit maag sudah baik. 


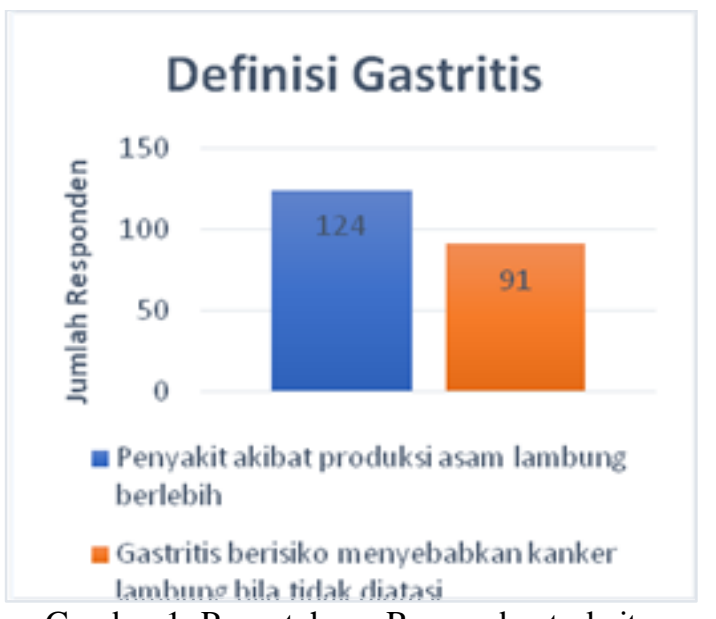

Gambar 1. Pengetahuan Responden terkait Definisi Gastritis

Profil pengetahuan responden tentang gejala gastritis ditunjukkan oleh Gambar 2. Gejala gastritis seperti perih atau panas pada perut maupun ulu hati, kembung, mual, dan muntah terjadi akibat peradangan atau inflamasi pada mukosa lambung, (Melbourne's Department of Health, 2010). Responden yang menjawab benar bahwa gejala perih dan panas pada perut sebesar 91,5\% (n=119), gejala mual dan muntah sebesar $70,8 \% \quad(n=92)$, gejala perut kembung sebesar 48,5 \% $(n=63)$. Sedangkan responden menjawab ketiganya dengan benar hanya sebesar 38,5 \% $(n=50)$. Perbedaan jawaban responden dapat terjadi karena variasi gejala yang dialami oleh responden.

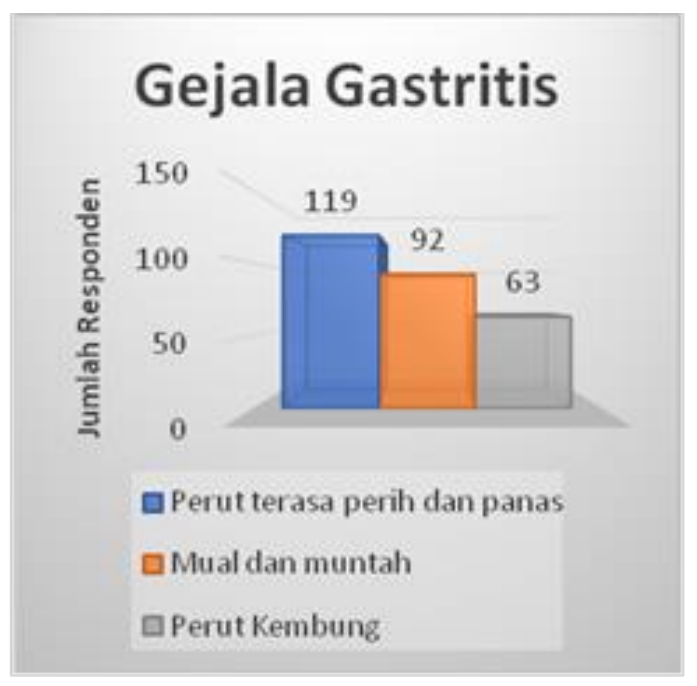

Gambar 2. Pengetahuan Responden terkait Gejala Gastritis

Profil pengetahuan responden mengenai cara mengatasi maag, definisi obat antasida, dan dosis pemakaian obat antasida ditunjukkan pada Tabel 2. Antasida merupakan obat yang digunakan untuk mengatasi gastritis dengan cara menetralkan kelebihan asam lambung (Hamid et al. 2014). Antasida tergolong dalam obat-obatan simtomatik sehingga hanya diminum apabila terjadi gejala maag. Akan tetapi, apabila setelah pengobatan antasida selama 3 hari dan gejala masih terus muncul bahkan memburuk, maka harus segera dirujuk ke dokter untuk mendapatkan diagnosis yang lebih tepat. Berdasarkan data Tabel 2 diketahui bahwa $98 \%(n=127)$ responden telah menjawab benar mengenai definisi antasida.

Berdasarkan Tabel 2, ditunjukkan bahwa 87 dari 130 responden $(66.92 \%)$ mengetahui bahwa dosis pemakaian antasida tablet untuk sekali minum adalah 1-2 tablet dan 110 dari 130 responden $(84.61 \%)$ mengetahui bahwa dosis pemakaian antasida cair untuk sekali minum adalah 1-2 sendok takar. Dosis awal antasida adalah 1 tablet atau 1 sendok takar, namun apabila gejala tidak mereda dapat menambahkan dosis yang diminum. Responden memliki pengetahuan yang baik mengenai dosis pemakaian obat antasida karena pada kemasan obat antasida telah tercantum informasi tersebut.

Tabel 2. Data Pengetahuan Responden

\begin{tabular}{|c|c|c|}
\hline Indikator & $\begin{array}{c}\text { Jumlah } \\
\text { Responden } \\
\text { Menjawab } \\
\text { Benar (n) } \\
\end{array}$ & $\%$ \\
\hline \multicolumn{3}{|l|}{ Cara Mengatasi Gastritis } \\
\hline $\begin{array}{l}\text { Segera ke dokter apabila } \\
\text { gejala tidak hilang lebih } \\
\text { dari } 3 \text { hari }\end{array}$ & 109 & 83,85 \\
\hline \multicolumn{3}{|l|}{ Definisi Obat Antasida } \\
\hline $\begin{array}{l}\text { Obat penetral asam } \\
\text { lambung }\end{array}$ & 127 & 98 \\
\hline \multicolumn{3}{|c|}{ Dosis Pemakaian Obat Antasida } \\
\hline $\begin{array}{lccr}\text { Dosis satu } & \text { kali } & \text { minum } \\
\text { adalah } 1-2 & \text { tablet } & \text { untuk } \\
\text { antasida tablet } & \end{array}$ & 87 & 66,92 \\
\hline $\begin{array}{l}\text { Dosis satu kali minum } \\
\text { adalah } 1-2 \text { sendok takar } \\
\text { untuk antasida cair }\end{array}$ & 110 & 84,61 \\
\hline
\end{tabular}

Profil pengetahuan mengenai waktu penggunaan obat antasida dapat dilihat pada Gambar 3. Sebanyak 67\% $(n=87)$ responden menjawab benar bahwa obat antasida harus diminum saat perut kosong, hal ini sesuai dengan anjuran Departemen Kesehatan RI (2008). Selain itu menurut Departemen Kesehatan RI (2007), obat antasida diminum 1 jam sebelum makan. 
Responden yang menjawab benar bahwa obat antasida diminum 1 jam sebelum makan sebesar $76 \% \quad(n=99)$. Sebanyak 48\% $(n=62)$ responden menjawab benar bahwa obat antasida dapat diminum 2 jam setelah makan. Berdasarkan Tabel 6, juga diperoleh sebanyak $90 \%$ responden $(n=117)$ menjawab benar bahwa obat antasida diminum saat timbul gejala maag. Menurut Departemen Kesehatan RI (2008), antasida paling baik diberikan saat muncul atau diperkirakan akan muncul gejala. Sedangkan responden menjawab keempatnya dengan benar hanya berjumlah $26,15 \%(n=34)$.

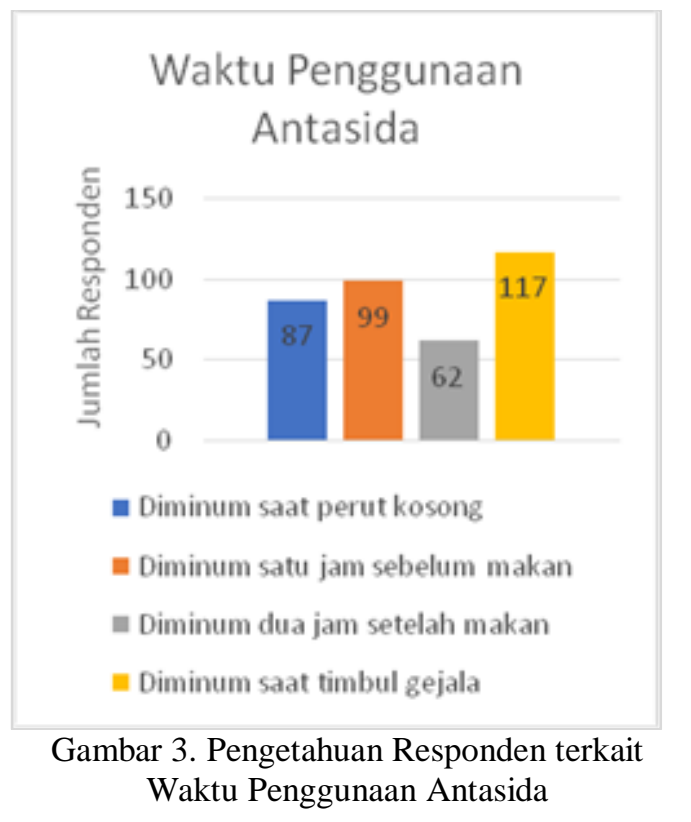

Profil pengetahuan tentang cara penggunaan, efek samping, cara penyimpanan, dan cara pembuangan obat antasida ditunjukkan pada Tabel 3. Berdasarkan Tabel 3, ditunjukkan sebanyak $85 \%$ responden $(n=111)$ mengetahui bahwa obat antasida cair harus dikocok dahulu sebelum diminum. Dari Tabel 3, ditunjukkan bahwa sebanyak 29\% responden $(n=38)$ mengetahui bahwa obat antasida tablet harus dikunyah dahulu sebelum ditelan. Sehingga terlihat bahwa pengetahuan responden mengenai cara penggunaan obat antasida tablet kurang baik. Menurut Departemen Kesehatan RI (2008), obat antasida seharusnya dikunyah dahulu baru ditelan. Hal ini dapat disebabkan karena informasi cara penggunaan obat antasida yang benar kurang disosialisasikan.

Tabel 3 juga menunjukkan bahwa terdapat 45 responden (34.61\%) dari 130 responden yang mengetahui bahan aktif antasida dapat menyebabkan diare atau bahkan susah BAB. Efek samping yang timbul tergantung dari bahan aktif yang terkandung di dalam antasida. Sediaan yang mengandung magnesium mungkin dapat menyebabkan diare, sedangkan yang mengandung aluminium mungkin dapat menyebabkan konstipasi (BPOM RI, 2015). Kurangnya pengetahuan responden mengenai efek samping obat antasida mungkin disebabkan karena responden tidak merasakan adanya efek samping yang timbul setelah minum obat antasida. Selain itu, kurangnya pengetahuan responden juga dapat disebabkan oleh responden yang tidak pernah mengalami sakit maag.

Tabel 3. Data Pengetahuan Responden Mengenai Antasida

\begin{tabular}{lc}
\hline \hline \multicolumn{1}{c}{ Indikator } & $\begin{array}{c}\text { Jumlah } \\
\text { Responden } \\
\text { Menjawab } \\
\text { Benar n (\%) }\end{array}$ \\
\hline $\begin{array}{l}\text { Cara Penggunaan Obat Antasida } \\
\text { Antasida cair harus dikocok } \\
\text { dahulu sebelum diminum }\end{array}$ & $\begin{array}{c}111 \\
(85 \%)\end{array}$ \\
\hline $\begin{array}{l}\text { Antasida tablet harus } \\
\text { dikunyah dahulu sebelum } \\
\text { ditelan }\end{array}$ & 38 \\
\hline Efek Samping Obat Antasida & $(29 \%)$ \\
\hline $\begin{array}{l}\text { Bahan Aktif Antasida berisiko } \\
\text { menyebabkan diare dan/atau } \\
\text { susah BAB }\end{array}$ & $\begin{array}{c}45 \\
\text { Cara Penyimpanan Obat Antasida }\end{array}$ \\
\hline $\begin{array}{l}\text { Antasida tidak dapat disimpan } \\
\text { dalam kulkas/lemari } \\
\text { pendingin }\end{array}$ & $\begin{array}{c}63 \%) \\
\text { Cara Pembuangan Obat Antasida }\end{array}$ \\
\hline $\begin{array}{l}\text { Antasida yang kadaluwarsa } \\
\text { tidak dapat dibuang langsung } \\
\text { dalam kemasan aslinya }\end{array}$ & $(48,46 \%)$ \\
\hline \hline
\end{tabular}

Berdasarkan Tabel 3, ditunjukkan bahwa sebesar 63 dari 130 responden $(48.46 \%)$ mengetahui bahwa obat antasida tidak dapat disimpan di dalam kulkas atau lemari pendingin. Penyimpanan obat antasida seharusnya pada suhu kamar dan terlindung cahaya matahari. Tabel 3 menunjukkan hanya terdapat $39,23 \% \quad(\mathrm{n}=51)$ responden yang mengetahui cara pembuangan obat antasida yang benar, yaitu obat antasida kadaluwarsa tidak dapat langsung dibuang dalam kemasan aslinya. Antasida tablet perlu dihancurkan terlebih dahulu lalu membuang obat dan kemasan secara terpisah.Sedangkan, antasida cair dibuang di saluran air lalu kemasannya dihancurkan. Terdapat banyak responden yang tidak mengetahui cara pembuangan obat antasida, karena kurangnya sosialisasi tentang cara pembuangan obat antasida yang benar. 


\section{Data Perilaku Responden}

Profil perilaku responden terkait penggunaan antasida dan penyakit maag dapat ditunjukkan pada Tabel 4. Berdasarkan data tersebut, 65,63\% $(\mathrm{n}=84)$ responden pernah mengalami sakit maag. Data lain yang dapat diperoleh adalah frekuensi timbulnya gejala maag yakni mayoritas 1 kali dalam seminggu. Banyaknya responden yang mengalami sakit maag dapat dimungkinkan adanya kaitan dengan tempat tinggal responden, khususnya responden yang bertempat tinggal di kos dan juga faktor usia dalam kategori produktif. Selain itu, cara responden mendapatkan obat antasida bervariasi seperti di apotek, warung, supermarket, atau dari orang lain. Seharusnya pembelian obat dilakukan di apotek karena kualitas obat lebih terjamin seperti tempat penyimpanan obat yang telah terstandar sesuai perundang-undangan serta mendapatkan informasi dari apoteker. Berdasarkan Tabel 3, ditunjukkan bahwa sebesar 63 dari 130 responden $(48.46 \%)$ mengetahui bahwa obat antasida tidak dapat disimpan di dalam kulkas atau lemari pendingin. Penyimpanan obat antasida seharusnya pada suhu kamar dan terlindung cahaya matahari. Tabel 3 menunjukkan hanya terdapat $39,23 \% \quad(n=51)$ responden yang mengetahui cara pembuangan obat antasida yang benar, yaitu obat antasida kadaluwarsa tidak dapat langsung dibuang dalam kemasan aslinya. Antasida tablet perlu dihancurkan terlebih dahulu lalu membuang obat dan kemasan secara terpisah. Sedangkan, antasida cair dibuang di saluran air lalu kemasannya dihancurkan. Terdapat banyak responden yang tidak mengetahui cara pembuangan obat antasida, karena kurangnya sosialisasi tentang cara pembuangan obat antasida yang benar.

\section{Data Perilaku Responden}

Profil perilaku responden terkait penggunaan antasida dan penyakit maag dapat ditunjukkan pada Tabel 4. Berdasarkan data tersebut, 65,63\% $\quad(n=84)$ responden pernah mengalami sakit maag. Data lain yang dapat diperoleh adalah frekuensi timbulnya gejala maag yakni mayoritas 1 kali dalam seminggu. Banyaknya responden yang mengalami sakit maag dapat dimungkinkan adanya kaitan dengan tempat tinggal responden, khususnya responden yang bertempat tinggal di kos dan juga faktor usia dalam kategori produktif. Selain itu, cara responden mendapatkan obat antasida bervariasi seperti di apotek, warung, supermarket, atau dari orang lain. Seharusnya pembelian obat dilakukan di apotek karena kualitas obat lebih terjamin seperti tempat penyimpanan obat yang telah terstandar sesuai perundang-undangan serta mendapatkan informasi dari apoteker. Jumlah responden yang menjawab bahwa pembelian obat yang benar adalah di apotek sebesar 43,08\% ( $\mathrm{n}=56)$ sedangkan lainnya memilih lebih dari satu jawaban atau memilih jawaban yang kurang tepat. Hal ini menunjukkan perilaku mahasiswa ITS untuk membeli obat di tempat yang benar masih tidak tepat. Penyebab perilaku tersebut kemungkinan karena susahnya akses ke apotek. Selain itu, berdasarkan data pada Tabel 4 dapat diketahui bahwa umumnya bahwa mahasiswa ITS sudah mengetahui tentang bentuk sediaan obat antasida. Bentuk sediaan obat antasida yang paling umum adalah sediaan cair dan sediaan padat.

Tabel 4. Data Perilaku Responden

\begin{tabular}{cccc}
\hline \multirow{2}{*}{$\begin{array}{c}\text { Perilaku } \\
\text { Responden }\end{array}$} & $\begin{array}{c}\text { Kategori } \\
\text { Jawaban }\end{array}$ & $\begin{array}{c}\text { Jumlah } \\
(\mathrm{n})\end{array}$ & $\%$ \\
\hline Riwayat Maag & Pernah & 84 & 65,63 \\
\hline \multirow{3}{*}{ Frekuensi Maag } & Tidak Pernah & 44 & 34,38 \\
\cline { 2 - 4 } & Sering & 4 & 4,76 \\
\cline { 2 - 4 } & Kadang & 11 & 13,10 \\
\cline { 2 - 4 } Cara & Jarang & 69 & 82,14 \\
\hline Mendapatkan & Apotek & 75 & 62,50 \\
\cline { 2 - 4 } Obat Antasida & Supermarket & 19 & 15,83 \\
\cline { 2 - 4 } & Warung/Toko & 13 & 10,83 \\
\cline { 2 - 4 } & Orang Lain & 13 & 10,83 \\
\hline \multirow{3}{*}{$\begin{array}{c}\text { Bentuk Sediaan } \\
\text { Yang Diketahui }\end{array}$} & Cair Saja & 25 & 18,94 \\
\cline { 2 - 4 } & Tablet Saja & 47 & 36,61 \\
\cline { 2 - 4 } & Cair Dan & 46 & 34,85 \\
\cline { 2 - 4 } & Tablet & 14 & 10,61 \\
\hline \hline
\end{tabular}

\section{KESIMPULAN}

Berdasarkan survei yang telah dilakukan oleh peneliti, dapat ditarik kesimpulan bahwa pengetahuan mahasiswa Institut Teknologi Sepuluh Nopember Surabaya terhadap penggunaan obat antasida sudah cukup baik. Namun, masih terdapat beberapa pengetahuan yang sebaiknya ditingkatkan, seperti cara penggunaan tablet antasida dan efek samping yang dapat ditimbulkan apabila menggunakan antasida.

\section{DAFTAR PUSTAKA}

Anggita, N 2012, Hubungan Faktor Konsumsi Dan Karakteristik Individu Dengan Persebsi Gangguan Lambung Pada Mahasiswa. Universitas Indonesia, Depok. 
BPOM RI 2015, Informatorium Obat Nasional Indonesia (IONI) (viewed 8 September 2019), http://pionas.pom.go.id/ioni/bab-1sistem-saluran-cerna-0/11-dispepsia-danrefluks-gastroesofagal/111-antasida-dansimetik- 0 .

Departemen Kesehatan RI 2007, Pedoman Penggunaan Obat Bebas Dan Bebas Terbatas. Direktorat Bina Farmasi Komunitas dan Klinik Ditjen Bina Kefarmasian dan Alat Kesehatan Departemen Kesehatan RI, Jakarta.

Departemen Kesehatan RI 2008, Materi Pelatihan Peningkatan Pengetahuan dan Keterampilan Memilih Obat Bagi Tenagan Kesehatan. Departemen Kesehatan RI, Jakarta.

Depkes RI 2011, Profil Data Kesehatan Indonesia (viewed 25 Maret 2015), http://www.depkes.go.id/downloads/PROFI L-DATA-KESEHATAN-INDONESIATAHUN 2011.pdf.

Hamid, R, Achmad, GNV, Wijaya, IN, Yuda, A 2014, 'Profil penggunaan obat antasida yang diperoleh secara swamedikasi (studi pada pasien apotek ' $\mathrm{X}$ ' Surabaya)', Jurnal Farmasi Komunitas, 1(2), pp. 49-52.

Holzer, P 2015, 'Acid-sensing ion channels in gastrointestinal Neuropharmacology, 94, pp. 72-79.

Kementerian Kesehatan RI 2012, Profil Kesehatan Indonesia 2011. Kementerian Kesehatan RI, Jakarta.

Kim, MK, Ko, BJ, Kim, EY, Han BD, Cho, KH 2015, 'Fast eating speed increases the risk of endoscopic erosive gastritis in Korean adults', Korean Journal of Family Medicine, 36(6), pp. 300-304.

Lim, SL, Canavarro, C, Zaw, MH, Zhu, F, Loke, WC, Chan, YH, Yeoh, KG 2012, 'Irregular meal timing is associated with helicobacter pylori infection and gastritis', International Scholarly Research Network Nutrition, 2013, pp. 1-7

Liveina, Artini, IGA 2014, 'Pola konsumsi dan efek samping minuman mengandung kafein pada mahasiswa program studi pendidikan dokter fakultas kedokteran Universitas Udayana', Jurnal Medika Udayana, 3(4), pp. 414-426.

Megha, R, Farooq, U, Lopez, PP 2020, StressInduced Gastritis, StatPearls Publishing, Treasure Island.

Melbourne's Department of Health 2010, Gastritis, Victorian Government, Melbourne.

Nathan, A 2008, Managing Symptoms in the Pharmacy, 1st Ed, Pharmaceutical Press, London.

Natun, RE, Candrawati, E, Warsono 2017, 'Hubungan konsumsi alkohol dengan nyeri lambung pada mahasiswa laki-laki program studi teknik sipil Universitas Tribhuwana Tunggadewi Malang', Nursing News, (2)3, pp. 398-406.

Putri, RN, Ernalia, Y, Bebasari, E 2015, 'Gambaran sindroma dispepsia fungsional pada mahasiswa fakultas kedokteran Universitas Riau angkatan 2014', Jurnal Online Mahasiswa Fakultas Kedokteran, (2)2, pp. 3-19.

Sulastri, Siregar, MA., Siagian, SA 2012, 'Gambaran pola makan penderita gastritis di wilayah kerja puskesmas Kampar Kiri Hulu Kecamatan Kampar Kiri Hulu Kabupaten Kampar Riau tahun 2012', Jurnal Gizi, Kesehatan Reproduksi Dan Epidemiologi, (1)2, pp. 1-9.

Susanti, A, Briawan, D, Uripi, V 2011, 'Faktor Risiko Dispepsia pada Mahasiswa Institut Pertanian Bogor (IPB)', Jurnal Kedokteran Indonesia, 2(1), pp. 80-91. 